\title{
RUSSO-JAPANESE TERRITORIAL DISPUTE FROM THE BORDER REGION PERSPECTIVE
}

\author{
Yukiko Kuroiwa ${ }^{1}$
}

Iwate Prefectural University

\begin{abstract}
:
Due to the territorial dispute created at the end of World War II, Japan and the Soviet Union/Russia have been in opposition and have yet to conclude a peace treaty. The territorial negotiations between Japan and Russia which resumed with the conclusion of the Cold War have continued for more than twenty years. However, there is no resolution in sight. Japan has been demanding the return of the Northern Territories (Southern Kuril Islands, according to their Russian definition), which are under Russian administration. Why is it that Japan and Russia cannot compromise over the issue of the ownership of these small islands? The purpose of this article is to demonstrate where the difficulties are in resolving this problem from a border region perspective. First, the article will trace the origins of, and shifts in, the territorial dispute, and next, examine the standpoints of the indigenous peoples and Japanese who formerly inhabited the Kurile Islands, as well as the Russians who presently reside there. Also, it will investigate the situation in Nemuro, Hokkaido, which practically lies in the RussoJapanese border region. As the resolution of the territorial dispute is drawn out, a "territorial myth" is established in which both sides, Japanese and Russian, state that the Northern Territories (Southern Kurile Islands) is rightfully their territory, making resolution all the more difficult.
\end{abstract}

Keywords: the Northern Territories, Southern Kurile Islands, Border Region, Russo-Japanese Territorial Dispute, Territorial Myth.

\section{Resumen:}

Debido a la disputa territorial creada a partir del final de la II Guerra Mundial, Japón y la Unión Soviética llevan manteniendo posturas opuestas y tienen desde entonces como consecuencia, pendiente la firma de un tratado de paz. Las negociaciones territoriales entre Japón y Rusia que se reanudaron con el fin de la Guerra Fría se llevan manteniendo desde hace más de veinte años. Sin embargo, no hay resolución a la vista. Japón persiste en su petición de que le sean devueltos los conocidos como Territorios del Norte (Islas Kuriles del Sur, según su definición rusa) y que efectivamente se mantienen bajo administración rusa. ¿Cuál es la razón por la que Japón y Rusia son incapaces de alcanzar acuerdo alguno sobre la posesión de estas pequeñas islas? El propósito de este artículo es el de demostrar dónde se sitúan los obstáculos que se interponen en la resolución de esta disputa desde la perspectiva de una región fronteriza. En primer lugar, este artículo reastrea los orígenes y vicisitudes de la disputa y a continuación, examina las posturas de los pueblos indígenas y japoneses que anteriormente habitaban las Islas Kuriles, así como de la población rusa que actualmente reside en ellas. Se va a examinar igualmente la situación en Nemuro, Hokkaido, que se encuentra cerca de la frontera Rusia-Japón. Al haberse hecho esperar tanto la resolución de la disputa territorial, se han acabado estableciendo "mitos territoriales" a ambos lados de la frontera, reforzándose con ello las respectivas narrativas, lo cual hace que la resolución de la disputa se vuelva aún más difícil.

Palabras clave: Territorios del Norte, Islas Kuriles del Sur, región fronteriza, disputa territorial ruso-japonesa, mito territorial.

Copyright $(9)$ UNISCI, 2013.

Las opiniones expresadas en estos artículos son propias de sus autores, y no reflejan necesariamente la opinión de UNISCI. The views expressed in these articles are those of the authors, and do not necessarily reflect the views of UNISCI.

\footnotetext{
${ }^{1}$ Yukiko Kuroiwa is associate professor at the Center for Liberal Arts Education and Research of the Iwate Prefectural University, teaching on history of thought, foreign language education and international relations. E-Mail: kuroiwa@iwate-pu.ac.jp.
} 


\section{Introduction}

In the summer of 2012, Japan's foreign policy was put under pressure by the simultaneous escalation of three territorial disputes. In July, Russian Prime Minister Dmitry Medvedev paid a visit to the 'Northern Territories' (Southern Kurile Islands) and in August, South Korean President Lee Myung-bak visited Tokdo (Takeshima). The purpose of both visits was to underlie the Russian and Korean possession of the respective territories. Since both territories are considered by Japan as its own territory, the visits had a negative impact on Japan's relations with the two countries. In September, China and Taiwan fiercely reacted to Japan's nationalization of the Senkaku Islands (Dyaoyutai). In mainland China, anti-Japanese protests became violent and in a number of cases involved attacks and pillaging of Japanese businesses.

All three of the territorial disputes involve small islands located on the remote fringes of Japan. However, there are some important differences between the Northern Territories dispute and the other two. Firstly, while Takeshima and the Senkakus are mostly uninhabited ${ }^{2}$, the Northern Territories have had permanent residents for a significant time. Today, there are approximately 17,000 Russian citizens permanently living on the islands. ${ }^{3}$ Secondly, unlike Takeshima and the Senkakus, there are numerous public documents related to the Northern Territories. These include historical Japanese and Russian documents related to the Kurile Island chain, various bilateral conventions and other international agreements. The third difference is that while in the case of Takeshima and the Senkakus, the positions of the Japanese on one side and the Korean, Chinese and Taiwanese on the other, exist in direct opposition to each other, however in the case of the Northern Territories, the Russian government admits the existence of a dispute and continues to negotiate with the Japanese government. After the visit of Medvedev to Kunashir, Russian President Vladimir Putin met with the Japanese Prime Minister Yoshihiko Noda in September 2012 in Vladivostok and both reached an agreement that negotiations aimed at finding a solution to the dispute would continue ${ }^{4}$.

Arguably, the most logical solution to the Northern Territories dispute would be a highlevel political agreement that would consider the human rights of the current residents of the disputed territory and reflect the various international legal agreements relevant to the dispute. However, so far both states have failed to find a mutually acceptable solution. The purpose of this paper is to analyze the continuing difficulties of the Japan-Russia territorial dispute from a 'border region' perspective.

The 'Northern Territories' that Japan demands to be returned by Russia consist of the islands of Iturup, Kunashir, Shikotan and Habomai archipelago, located at the Southern part of the Kurile chain. The overall territory claimed by Japan is about $5000 \mathrm{sq}$. km. Habomai is actually an archipelago but for the sake of convenience is considered as one island. Thus, combined the islands are called in Japan as the 'Four Northern Islands'. The Kurile chain consists of thirty islands of various sizes and numerous rocks that stretch over 1200

\footnotetext{
${ }^{2}$ To be more precise, since 1991 there are two or three Korean fishermen residing on Takeshima. On the Senkakus, some Japanese fishermen resided from the end of $19^{\text {th }}$ century till the end of WWII. At its peak, the population has reached 200 residents.

${ }^{3}$ According to the Russian Federal Statistics Agency, as of January $1^{\text {st }} 2012$, the population of the islands is 16 , 969: ГОСКОМСТАТ РОССИИ: "Численность населения российской федерации по городам, рабочим поселкам и районам на 1 января 2012 г." (2012).

4"Japan-Russia Summit Meeting on the Occasion of APEC Leaders' Meeting in Vladivostok (Overview)", 8 September 2012, at http://www.mofa.go.jp/announce/jfpu/2012/09/0908-03.html.
} 
kilometers from the southern tip of the Kamchatka peninsula to the eastern part of Hokkaido. Waters adjacent to the islands are abundant in fish and in terms of marine resources are considered to be one of world's richest areas. Since ancient times, the Kurile archipelago was known in Japan as the Chishima archipelago. However, the Japanese official position in the dispute states that the 'Northern Territories' are not part of Chishima but Japan's 'inherent territory' that has never been part of another country. Contrastingly, in Russia, these islands are referred to as the 'Southern Kuriles'. In this paper I will use both 'Southern Kuriles' and 'Northern Territories' interchangeably to refer to the disputed islands.

This paper will proceed as follows. First, it will examine the historical shifts in JapanRussia border, the history of the territorial dispute and the ways past and present residents of the Kurile islands have related to this dispute. It will continue to analyze the situation of Nemuro, a town located at the eastern tip of Hokkaido, across the strait from South Kuriles, in an area which can is basically a border region. After outlining Japanese and Russian governmental attitudes towards the disputed area, the paper will conclude by sketching some possible future developments in the territorial dispute.

\section{The Shifting Border between Russia and Japan}

\subsection{Conditions in Northern Japan prior to the Territorial Dispute}

Russian people first crossed Siberia and arrived in the Kurile Island chain at the beginning of the $18^{\text {th }}$ century. From there they proceeded southward along the chain, collecting from the local indigenous people valuable sea otter furs as a form of taxation. As the administrator of a vast region stretching from Siberia to North America and seeking furs and mineral resources, Russian interest in Japan as a potential trading partner and supplier of provisions and commodities increased greatly. Though the activities of Japanese people in the area at that time were limited to small scale fishing operations, in 1800 the Edo Shogunate, spooked by Russia's southward advance, set about establishing an administrative office on the island of Iturup.

Concluded in 1855 between Russia and Japan, the Treaty of Shimoda determined that "the boundaries between Russia and Japan will pass between the islands Iturup and Urup... The island Karafuto (Sakhalin), will remain unpartitioned between Russia and Japan".5 Twenty years later, in 1875, the two countries concluded the Treaty of St. Petersburg, changing their national boundaries. Sakhalin came under Russian control while all remaining Kurile Islands north of Urup were handed over to Japan, giving Japan ownership of the entire Kurile chain. The border was changed yet again another thirty years later in 1905, when in the Treaty of Portsmouth Russia ceded Sakhalin's southern half to Japan.

Prior to Russian and Japanese expansion into the areas north of Japan, local indigenous people maintained a primitive way of life through fishing and hunting. The northern Kurile Islands were inhabited by the Chishima Ainu people while the southern islands were inhabited by Hokkaido Ainu, each conducting exchanges with the other. However, the drawing up of borders by Russia and Japan across the archipelago divided their territories, forcing them to choose between Russian and Japanese nationality and, due to forced migration and policies of

\footnotetext{
${ }^{5}$ Ministry of Foreign Affairs of the Russian Federation and Ministry of Foreign Affairs of Japan (1992): "Sovmestny isbornik dokumentov po istorii territorial'nogo razmezhevaniya mezhdu Rossieii i Yaponiei ", Moscow, Tokyo, p. 9.
} 
assimilation, these people gradually declined. ${ }^{6}$

Once the Kuriles and the southern half of Sakhalin became Japanese territory, indigenous populations were displaced by Japanese who came to live there. The Southern Kuriles developed as part of a fishery based around Nemuro on Hokkaido and at the end of WWII contained a population of around 17,000 people. ${ }^{7}$ The central Kurile Islands remained unpopulated, while the northern islands, though having few established residents, became a base for fishing operations in the northern Pacific and saw up to 18,000 fishermen visit from the Japanese mainland during the fishing season. ${ }^{8}$ On the southern half of Sakhalin, fisheries, agriculture and paper manufacturing industries expanded and its population grew to more than 400,000 people. ${ }^{9}$

Ever since the Russo-Japanese War, Japan and Russia/the Soviet Union have clashed repeatedly. Upon the breakout of revolution in Russia, Japan sent its army into Siberia, occupying the northern part of Sakhalin and placing the entire island under its control from 1920-25. In 1925, Japan and the Soviet Union established diplomatic relations by signing a Convention of Basic Principles. Nevertheless, once the de facto Japanese colony of Manchukuo was established in north-eastern China, military clashes between Japanese and Soviet armies occurred repeatedly along the Soviet-Manchukuo border.

In December 1941 the Japanese combined fleet set out from Iturup and attacked Pearl Harbour in Hawaii, entering into total war against the Allied Powers. Although military personnel were stationed along the Kurile chain, the islands remained quiet and had little experience of supply shortages or of any military tension. As Japan and the Soviet Union had concluded a five-year Neutrality Pact in April 1941, the Japanese people did not conceive of war with the Soviets. Moreover, when Japan's defeat became all but certain in July 1945, the Japanese government had appealed to the Soviet Union to act as intermediary for a cease-fire with the United States.

\subsection{Origins and Evolution of the Territorial Dispute}

The seeds of the Russo-Japanese territorial dispute can be found in the Yalta Agreement signed behind closed doors in February 1945 between the United States, the United Kingdom and the Soviet Union. The US, which at that time had yet to successfully develop the nuclear bomb, hoped for the Soviet Union to open a front against Japan in the Far East. As compensation, Stalin sought the transfer of Japanese territory. In contradiction of the principle of non-expansion, the Yalta Agreement established that "The southern part of Sakhalin as well as all islands adjacent to it shall be returned to the Soviet Union.... The Kurile Islands shall be handed over to the Soviet Union". ${ }^{10}$ This agreement was made public in February 1946, a full year after it was brokered.

\footnotetext{
${ }^{6}$ In 1884, ninety-seven Chishima Ainu were forcefully relocated by the Japanese government from the northern Kuriles to Shikotan Island and, unable to adapt to the new environment, these people died out; see: Zajac, Malgorzata (2009): Chishima Ainu no kiseki, Tokyo, Sofukan; Kosaka, Yosuke (1992): Rubo, Nichiro ni owareta Kita-chishima ainu, Sapporo, Hokkaido Shimbunsha.

${ }^{7}$ The population of the Southern Kuriles as of 15 August, 1945 was 17,291 people: Ministry of Foreign Affairs of Japan (2012): Warera no Hopporyodo 2011, Tokyo, p.9.

${ }^{8}$ Hokkaido government (1957): Chishima chosasho, Sapporo, Hokkaido Government, p. 23.

${ }^{9}$ The population of the southern half of Sakhalin as of 31 December, 1944 was 417, 976 people. Additionally, Japanese army personnel and Koreans conscripted into the Japanese army were also based there: Wakatsuki, Yasuo (1995): Sengo hikiage no kiroku, Tokyo, Jijitsushinsha, p.99.

${ }^{10}$ Ministry of Foreign Affairs of the Russian Federation and Ministry of Foreign Affairs of Japan, op.cit., p.21.
} 
In August 1945 the Soviet Union broke the still active neutrality pact and declared war against Japan, invading north-eastern China and the Korean Peninsula. The Soviet Union commenced its attack on 9 August, the same day on which an atomic bomb was dropped on the city of Nagasaki, following in the wake of the nuclear attack on Hiroshima. On the 14 August Japan accepted the Potsdam Declaration and surrendered, however the Soviet offensive continued and both southern Sakhalin and the Kurile chain were occupied. ${ }^{11}$ The occupation of the Southern Kuriles was complete by 5 September, after Japan has already signed the instrument of surrender to the Allies on 2 September. Around 20,000 Japanese officers and men on the Southern Kuriles became prisoners, and most were interned in Siberia. $^{12}$

Thus Sakhalin and the Kurile chain fell to Soviet control and a de-facto border known as the 'middle line' was drawn between these islands and Hokkaido. From April 1946, Soviet border patrols began seizing Japanese fishing vessels caught crossing this line. This practice has continued until the present day. ${ }^{13}$ In February 1946, the Region (oblast') of South Sakhalin was officially established in the occupied territory. This was expanded in January 1947 to include the north Sakhalin, together now forming the territory of Sakhalin Region (oblast'), and all place names were changed to Russian names. At the end of WWII most Japanese people living in Sakhalin returned to Japanese mainland, and by 1948 all Japanese people who had remained in the Southern Kuriles had been expelled. The new residents of Sakhalin, replacing the Japanese, were to be Soviet citizens assembled from every part of the Union within the framework of a colonial settlement policy. In the Northern and Southern Kuriles, fishing industries were expanded using the infrastructure, industrial facilities and housing built by the Japanese. Sakhalin had "made the transition from capitalism to socialism" within the extremely short timeframe between the end of August 1945 to January $1947 .{ }^{14}$ By the beginning of the 1950s, Sakhalin Region's population reached 480,000 people, and by the time of the opening of the San Francisco Peace Conference it was fully established as an administrative region of Soviet Russia. ${ }^{15}$

With its signing of the San Francisco Peace Treaty in September 1951 along with fortyeight other countries, Japan made its return to international society. The peace treaty, framed under the leadership of the United States and in accordance with the Yalta Agreement, made clear that Japan would renounce ownership of the Kurile chain and southern Sakhalin. However, the treaty failed to clearly demarcate the extent of the Kurile Islands, nor did it indicate which country the abandoned territories would belong to, thus sowing the seeds of

\footnotetext{
${ }^{11}$ On the northern Kurile island of Shumshu a brutal encounter between Japanese forces and the Soviet army which had launched an attack from the Kamchatka Peninsula, saw more than 1,500 dead on both sides between August 18-23: Itani, Hiroshi: "Shumushu Island in August 1945”, Japan Border Review, no. 2 (Nov. 2011), p. 31; Slavinsky, Boris (1993): Chishimasenryo, 1945 nennatsu, Tokyo, Kyodo Tsushin sha, pp.120-121.

${ }^{12}$ Ibid., p.156. Russian Academy of Science, Institute of Geography RAS and Pacific Institute of Geography RAS Far Eastern Branch (2009): Atlas of the Kuril Islands, Moscow, Vladivostok, Publishing and Production Center "Design, Information, Cartography", p.109.

${ }^{13}$ The Nemuro branch of the Japanese Coast Guard confirms 1, 339 vessels seized and 9, 489 people detained between the years 1946-2008: Honda, Ryoichi: "Nichiro kankei to anzensogyo", Making a Discipline of Slavic Eurasian Studies, no.15 (July 2006), p. 67; Nemuro-shi and Hopporyodo Mondai Taisaku Kyokai (2009): Nihon no ryodoHopporyodo, Nemuro, Tokyo, pp. 91-92.

${ }^{14}$ Vysokov, Mikhail; Vasilevskii, Aleksandr; Kostanov, Aleksandr and Ischenko, Marina (2008): Istoriya Sakhalina $i$ Kuril'skikh ostrovov $s$ drevneishikh vremen do nachala XXI stoletiya,Yuzhno-Sakhalinsk, Sakhalinsko eknizhnoe izdatel'stvo, p. 454.

${ }^{15}$ Vysokov, Mikhail; Golebev, Valerii; Kozhukhova, Tamara; Kolesnikov, Nikolai; Lopachov, Aleksandr and Tvarkovskii, lev (1995): Istoriya Sakhalinskoi oblasti s drevneishikh vremen do nashikh dnei, YuzhnoSakhalinsk, p. 156.
} 
future discord between Japan and the Soviet Union. ${ }^{16}$ In his speech at the San Francisco Peace Conference, Prime Minister Yoshida Shigeru maintained that the islands of Habomai and Shikotan were parts of Hokkaido and could not be included in the Kuriles and that historically speaking, both Kunashir and Iturup were Japanese territory. Opposing to the content of the Peace Treaty, the Soviet Union did not sign. In the midst of increasing Cold War confrontation between the United States and the Soviet Union, Japan concluded its own Security Treaty with the US at the same time as the Peace Treaty.

Separate negotiations between Japan and the Soviet Union commenced in June 1955. Nikita Khruschev proposed that Shikotan and Habomai be handed over. However as Japanese negotiators made additional demands for the return of Kunashir and Iturup no peace agreement was reached. At the end of negotiations which lasted one year and five months, both countries signed a Soviet-Japanese Joint Declaration to restore diplomatic relations. The Joint Declaration made clear that the parties would continue negotiations for the conclusion of a peace treaty, and that the islands of Habomai and Shikotan would be returned to Japan once this was achieved.

Nevertheless, negotiations for a future peace treaty never resumed. In retaliation for Japan's renewal of the US-Japan Security Treaty in January 1960, the Soviet Union added as a further condition for the return of Habomai and Shikotan the withdrawal of all foreign armies from Japanese territory. In response, Japan asserted that it "would persist in demanding the return not only of the Habomai and Shikotan islands but of all territories which inherently belong to Japan". ${ }^{17}$ The two countries were now diametrically opposed.

In 1957, the Soviet Union removed the around 2000 Soviet citizens previously settled on the islands of Shikotan and Habomai in preparation for their handover. However, losing the determination to complete the transfer, it settled another 1500 laborers on Shikotan in 1960. The Habomai islands currently remain uninhabited. ${ }^{18}$

Until around 1960, Japanese domestic opinion was inconsistent regarding the extent of territory to be demanded back from the Soviet Union, with some voices pressing for the entire Kurile Chain and others for the return of Habomai and Shikotan only. While the Japanese government post-WWII had set its aim on the return of Habomai and Shikotan, the return of the four islands of Kunashir and Iturup, in addition to Habomai and Shikotan, has since

\footnotetext{
16 Within the San Francisco Peace Treaty the fates of other former Japanese possessions, such as Taiwan and Korea, was left unclear. For further detail on how this left Asian countries with unsolved territorial problems readers are encouraged to consult the following publication: Hara, Kimie (2007): Cold War Frontiers in the Asia-Pacific, Divided Territories in the San Francisco System, London, New York, Routledge.

${ }^{17}$ Ministry of Foreign Affairs of the Russian Federation and Ministry of Foreign Affairs of Japan, op.cit., pp. 3940.

${ }^{18}$ In February 1957 the Soviet Union closed a crab meat canning factory on the largest Habomai island of Zelenyi and decided in June of that year to close a seafood factory on Shikotan. In March 1960, however, a further two factories were slated for construction on Shikotan: Bondarenko, Oleg (1992): Neizvestnye Kurily, Moscow, VTI-Deita Press, p. 116; Wada, Haruki (2012): Ryodo mondai o do kaiketsu suruka, Tairitsu kara taiwa e, pp.150-151). According to Khruschev's memoirs, his motivation for offering to hand over the islands came from the fact that uninhabited Habomai and Shikotan islands would have had little value both economically and militarily, yet the amount of goodwill to be garnered from the Japanese people would be immense if they were returned. (Schecter, Jerrold L. and Luchkov, Vyacheslav V. (1990): Khruschev Remembers, The Glasnost Tapes, Boston; Toronto; London, Little Brown and Company, p. 89). Nevertheless, there were indeed inhabitants on these islands at the time, which can only mean that Khruschev was either ignorant of the actual conditions in the Southern Kuriles, or that his recollection is mistaken.
} 
become firmly entrenched government policy. ${ }^{19}$ Japan took on the position that these four islands do not belong to the Kurile chain, which Japan relinquished when it signed the San Francisco Peace Treaty. Japan also prohibited the use of the name 'Southern Kuriles' and officially named these islands the 'Northern Territories'. Moreover, since the latter half of the 1960s Japanese government has been actively involved in expanding the 'Movement for the Return of the Northern Territories'. For its part, the Soviet Union declared in 1961 that "territorial issues between Japan and the Soviet Union are resolved", denying the very existence of a dispute, breaking down negotiations over territory between the two countries. ${ }^{20}$

Only in the second half of the 1980s, when Gorbachev reforms were implemented, did serious discussions resume between the two countries. Both Japan and the Soviet Union adjusted their previous hardline stances, establishing a working group for the creation of a Soviet-Japan peace treaty and conducting rigorous discussion in eight meetings held between 1989 and 1991. As a result of having exhausted all legal and historical arguments concerning the disputed territories, diplomats on both sides jointly recognized that the only remaining option would be a political decision emerging from a high level leadership conference. ${ }^{21}$

With the collapse of the Soviet Union at the end of 1991, Boris Yeltsin, as president of a newly reborn Russia, picked up the negotiations and began to show a desire for a resolution to the territorial dispute. Commencing in 1992 was the program of 'visa-free exchange' which had been agreed to during the Soviet era. This program allows Japanese and Russian citizens from the Southern Kuriles to visit the other without the need for a visa, and is aimed at increasing mutual goodwill and understanding as well as contributing to the resolution of the dispute. $^{22}$

The 1993 Tokyo Declaration affirmed a resolve to settle issues relating to the ownership of the four islands and to conclude a peace treaty. ${ }^{23}$ Furthermore, Prime Minister Ryutaro Hashimoto and President Yeltsin agreed that they "(would) do their best to conclude a peace treaty by the year $2000 " .{ }^{24}$

The year 2000 came and went without producing any points of compromise between Japan and Russia, Vladimir Putin became the new Russian president, while Japan saw a continuous succession of prime ministers. The Irkutsk Statement signed by Prime Minister Yoshiro Mori and President Putin clarified the validity of the various past agreements between Japan and the Soviet Union/Russia, starting with the 1956 Joint Declaration, but little noticeable headway has been made since.

One of the causes for the breakdown in negotiations is the divergence between two camps of domestic opinion in Japan, with one insisting on the 'simultaneous return of the four islands' (yontō ikkatsu henkan) while the other demanding the 'return of two islands first'

\footnotetext{
${ }^{19}$ Hara, Kimie (1998): Japanese-Soviet/Russian Relations since 1945, a difficult peace, London, New York, Routledge, pp. 24-30.

${ }^{20}$ Suezawa, Shoji; Shigeta, Hiroshi and Kawabata, Ichiro (2003): Nichiro (Soren) Kihonbunsho • Shiryoshu (Kaiteiban), Tokyo, Zaidanhojin Radio Press, p.175.

${ }^{21}$ Panov, Alexander (1992): Fushin kara shinrai e, Hopporyodo kosho no uchimaku, Tokyo, The Simul Press INC., p. 60; Togo, Kazuhiko (1993): Nichiro shinjidai e no joso, Tokyo, The Simul Press INC., p. 74.

${ }^{22}$ Visa-free exchanges continue today, with 18,075 participants in total as of March, 2012. Cabinet Office, Government of Japan, at http://www.cao.go.jp/hoppo/shiryou/kouryu/html\#2.

${ }^{23}$ Ministry of Foreign Affairs of the Russian Federation and Ministry of Foreign Affairs of Japan (2001): Novoe izdanie sovmestnogo sbornika dokumentov po istorii territorial'nogo razmezhevaniya mezhdu Rossiei i Yaponiei, Moscow, Tokyo, p. 7.

${ }^{24}$ Ministry of Foreign Affairs of Japan (2012): 2011 nenban, Warera no Hopporyodo, Shiryohen, Tokyo, p. 46.
} 
(nitō senkō henkan) referring to Habomai and Shikotan. The opposition between these two camps ended when Diet member Muneo Suzuki, a particularly strong supporter of the two island solution, was arrested on suspicion of influence peddling in June 2002. As a result, diplomatic officials close to Suzuki also lost their standing and Japan lost some of its diplomatic strength vis-à-vis Russia. ${ }^{25}$ Meanwhile, President Putin has hinted at a settlement based on the handover of Habomai and Shikotan, as provided by the 1956 Soviet-Japanese Joint Declaration. Nevertheless, Japan has not ceased its demands for the return of all four islands.

\section{The Territorial Dispute from the Perspective of Kurile Island Residents}

\subsection{Indigenous People of the Kurile Islands}

Because of their absorption into the Japanese population, there were practically no pure blooded Ainu people on the Kurile Islands by the end of WWII. ${ }^{26}$ The few remaining Ainu people left the islands along with the Japanese population, becoming dispersed within Japanese society and disappearing. As a result, there are no remaining direct descendants of the indigenous people of the Kurile chain. However, there are moves towards claiming specific rights to the Northern Territories based on the argument that the indigenous people of the Kuriles are the ancestors of the Ainu people as a whole. In 2002, the Hokkaido Utari Association (from 2009, Hokkaido Ainu Association) adopted a policy to demand indigenous rights over the Northern Territories. ${ }^{27}$ A 2008 Indigenous Peoples Summit - 'Ainu Mosir' resolved that "the Ainu people must be included as sovereign owners in any negotiations for the return of the Northern Territories". Moreover, the Kurile-East Hokkaido Ainu Association was launched in 2009 with the intent to tackle issues concerning the disputed territories. ${ }^{28}$

In Russia, an Association for Northern, Siberian and Far Eastern Minorities was established in 1990 to assert the rights of indigenous groups, though there is no group advocating the rights of people indigenous to the Kuriles. ${ }^{29}$ In museums on Iturup and Kunashir one can find displays relating to the Ainu people indicating they were the original inhabitants of the Kurile Islands. However, the indigenous issue is often raised in opposition to Japanese demands for the return of the Northern Territories. Valentin Fyodorov, a former governor of the Sakhalin Region and a strong opponent of the return of the islands to Japan, requested that Ainu representatives be invited to a June 1992 Hokkaido-Sakhalin dialogue as he was aware of Ainu grievances against the Japanese government. Also, in October 2008 the head of the Russian delegation visiting Nemuro under the visa-free exchange program proposed making the Southern Kuriles an independent country of the Ainu, the islands'

\footnotetext{
${ }^{25}$ More than ten people were arrested on suspicion of irregularities relating to the Japanese aided construction of a diesel fueled power plant on the island of Kunashir, including Suzuki's secretary, diplomats and the employees of large trading and construction companies. Most of these were found guilty.

${ }^{26}$ Stephan, John (1974): The Kuril Islands, Russo-Japanese Frontier in the Pacific, Oxford, Clarendon Press, p. 110; Kodama, Sakuzaemon (1969): "Ainu no bumpu to jinko", in Ainu minzokushi, volume 1, Tokyo, Daiichi HokiShuppan, p.17.

${ }^{27}$ According to a 2006 survey by the Hokkaido regional government, the Ainu population of Hokkaido was 23, 782 people; Members of the Hokkaido Utari Association number 3, 234: Hokkaido Ainu Kyokai, at http://www.ainu-assn.or.jp.

${ }^{28}$ Hokkaido Shimbun, February 2, 2010.

${ }^{29}$ Morris-Suzuki, Tessa (2000): Henkyo kara nagameru, Tokyo, Misuzu Shobo, p.200.
} 
original inhabitants. $^{30}$

Meanwhile, the Japanese government has been silent regarding the original owners of the Kurile Islands, simply insisting that "the nation has inherited these lands from our forefathers". 31 In 2007 the United Nations adopted the Declaration on the Rights of Indigenous Peoples, and in October 2009 Yukio Hatoyama became the Japanese first prime minister to recognize the Ainu as an indigenous ethnic group of Japan. As such, both Japan and Russia will need to examine the position of indigenous peoples within the context of the current territorial dispute.

\subsection{Former Japanese Islanders}

The small number of Japanese islanders on the Northern Kurile Islands moved back to the Japanese mainland at the end of the war, scattering to different regions of the country. ${ }^{32}$ However, many of the roughly 17,000 former residents of the Southern Kuriles came to live in and around Nemuro in Hokkaido. As many of them were small-scale fishermen, they gravitated towards Nemuro as a center of the fishing industry. Due to the impoverished postwar conditions many of them ventured into the waters off the Kuriles to fish, only to be captured by Soviet border patrols.

As they struggled to maintain their livelihoods and had little to spare on becoming involved in the territorial dispute, it was not until 1958 that former islanders established their own group. As a corporation with the official approval of the Japanese prime minister, the League of Kurile-Habomai Residents (henceforth, 'the League') supported the welfare of impoverished former islanders as well as collecting signatures and submitting petitions to the National Diet for the return of the Southern Kuriles.

More energetic participation in the movement to return the islands amongst the former islanders began to occur from around 1965. According to former League chairman Mitsuo Takenami, former islanders were criticized by other activists seeking the return of the islands for being too self-serving, as they would speak only of their former lives and fishing ventures on the islands. Therefore, from around 1975 onwards, they avoided speaking of their individual stories, and if asked about the islands once returned to Japan would respond in the following manner: "We are not saying that the Kurile Islands are our lands. We want to use them for providing food for the whole of Japan and as a world utopia". Spearheading a movement for the return of the islands initiated by the Japanese government, the former islanders took on somewhat of a symbolic existence and thus could no longer afford to emphasize their individual losses of property and fishing rights. In 1964 Soviet authorities granted a permission on compassionate grounds to allow former Japanese residents to visit family graves on the Southern Kuriles without a visa. However in 1976 this was suspended for a period of ten years: the Soviet Union required former islanders to provide passports and obtain visas but this was prohibited by the Japanese government as undermining its claim to the islands. Only from 1992 were former islanders able to visit areas other than grave sites on the Southern Kuriles with the commencement of the visa-free exchange program. The League has stated that the role of former islanders within this program is to "deepen mutual understanding and friendship, and to contribute to an atmosphere congenial to the return of

\footnotetext{
${ }^{30}$ Hokkaido Shimbun, October 2, 2008.

${ }^{31}$ Ministry of Foreign Affairs of Japan, op.cit., p. 4.

${ }^{32}$ At the end of WWII, 82 households comprised of 109 people withdrew from the Northern Kuriles. Of these, only two households were living in Hokkaido in 1963: Hokkaido Government (1963): Kita chishima moto kyoju shasei katsu jittai chosa, Sapporo, pp. 1; 4.
} 
the territories". ${ }^{33}$ It has also overseen the delivery of humanitarian assistance to the economically impoverished Russian residents of the Southern Kuriles.

As of 31 March 2012, around sixty percent of the Japanese former islanders had passed away, leaving 7,260 survivors with an average age of seventy-eight. ${ }^{34}$ As only 2,420 people of that number remained as members, the League is currently seeking to develop its future successors. Descendants of former islanders, including the second, third and fourth generations, number around 36,000 people, but among those only 1,607 are League members, or four per-cent of the total. ${ }^{35}$ Furthermore, questions are being raised amongst second generation League members about the movement to restore the islands to Japan. For example, eighty-five members of the youth division of the Nemuro branch declared in a March 2007 general meeting of the League that the "current movement for achieving the simultaneous return of the four islands cannot overcome the present situation", showing a more flexible response towards the resolution of the territorial dispute. ${ }^{36}$

Work to compile interviews and commentaries by the now elderly former islanders is also being carried out. Most of the recollections contained in these paint a picture of the rich natural environment of their former Southern Kurile homelands, of a peaceful lifestyle and a spirit of cooperation on the islands, and also of the fear of Soviet invasion and of the sadness and hardships endured on being driven from their homeland. ${ }^{37}$ On comparison with survey results conducted by the Hokkaido regional government in 1939-1941, however, it is clear these new histories have been considerably beautified, and that a rewriting of collective memories has taken place amongst the former islanders: the government survey reveals an environment characterized by large numbers of ill and a high mortality rate due to heavy labor, harsh climate, austere diet and excessive alcohol consumption, a group of children without school education and entrenched closed attitudes to the people outside of islands. ${ }^{38}$

Since 2000, even the former islanders recognize that their work to reclaim the islands has reached a limit. With no obvious prospects for the solution of the territorial dispute, there are some suggestions for compensation to be sought from the government for the loss of property rights and for the mental anguish that has continued for sixty years since the end of the war. $^{39}$

\subsection{Current Russian Residents}

For residents of the Southern Kuriles during the Soviet era, no territorial dispute ever existed. In 1974 John Stephen noted that "few places in the world today are more inaccessible to foreigners than the Kuril Islands". ${ }^{40}$ As this suggests, during the Soviet time, the residents of the Kuriles never heard demands for the return of the Southern Kuriles by Japan. If anything,

\footnotetext{
33 Chishima Habomai Shoto Kyojusha Renmei (ed.) (1997): Moto tominni yoru Hopporyodo henkan undo no ayumi, Sapporo, p.200.

34 Hopporyodo Mondai Taisaku Kyokai, at http://www.hoppou.jp.

35 Chishima Habomai Shoto Kyojusha Renmei, at http://chishima.or.jp/outline.htm; Nemuro-shi and Hopporyodo Mondai Taisaku Kyokai (2012): Nihon no ryodo, Hopporyodo, Nemuro, Tokyo, p.119.

${ }^{36}$ League of Kuril-Habomai Residents, Nemuro shibu seinenbu, "Undo hoshin ni kansuru ketui hyomei”, 19 March 2007.

${ }^{37}$ ChishimaHabomaiShotoKyojushaRenmei (2002-2006): OmoidenowagakokyoHopporyodo, Vol. 1-4, Sapporo. Chishima Habomai Shoto Kyojusha Renmei (1997-2001): Warerano shimano omoide, Vol. 1-10. (Video), Sapporo.

${ }^{38}$ Hokkaido Government (1957): Chishima chosasho, Sapporo, pp. 21;164.

${ }^{39}$ Chishima Habomai Shoto Kyojusha Renmei (2009): Chisima Renmei 50 nen no ayumi, Sapporo, p.46.

${ }^{40}$ Stephan, op.cit., p. 171.
} 
when these were broadcast by the Soviet authorities they were presented as illegal demands of Japanese militarists and those seeking retaliation against the Soviet Union.

The particular characteristic of Kurile society and economy is expressed in the word vremennost ('temporary'). Its economy specializes only in fishing, agricultural productivity is low and its construction and service industries are remarkably outdated. With little improvement to its infrastructure there is no option but to rely on fuel, food and daily necessities from outside the islands. That people come to live on islands such as these mainly as a result of a system of 'northern privileges', enacted on 1 August 1945 and still guaranteed under current Russian labor legislation. This allows the residents of the Kurile Islands to enjoy preferential treatment of the same type that exists for the far northern regions of Russia. These include a higher salary, guaranteed housing, extended vacation times and a lower retirement age. Many comparatively young residents are attracted to the island by such privileges, though there are also many cases of people leaving and returning to their hometowns upon reaching retirement age. Troops are also stationed on the islands along with a few thousand seasonal workers who stay only during the fishing season. Amongst these groups there is little ambition to help develop the islands. As a result, profits taken from the fishing industry are seldom returned to the islands and residents themselves live with the attitude that they too have merely come to make some money. ${ }^{41}$

The collapse of the Soviet Union, and the political and economic disorder that followed, had a huge impact on these 'temporary' islands. Rises in shipping costs slowed the movement of goods, while delays of several months in the payment of salaries amidst continuously rising prices impoverished island residents. These islanders used the opportunity of the visa-free exchange program begun in 1992 to appeal to Japanese delegations for economic cooperation.

The open-mindedness of Southern Kurile residents at the time in relation to the territorial dispute surprised the Japanese. In April 1993, a local referendum held in the village of Malokuril'skoe on Shikotan Island revealed that 83 percent of voters (or 916 people) supported the Soviet-Japanese Joint Declaration, which outlines the handing over of Shikotan and Habomai to Japan. ${ }^{42}$ Several surveys conducted by both Japan and Russia during that time show that a considerable number of residents approved of the return of the Southern Kuriles to Japan, in particular on the island of Shikotan. ${ }^{43}$

As for the reasons behind such flexibility shown by Southern Kurile residents, one can look to the favorable impressions of Japan garnered by its efforts to improve goodwill through the visa-free exchange program, as well as its provision of humanitarian aid. Also, having witnessed Japan's economic development and high living standards via the exchange

\footnotetext{
${ }^{41}$ Bondarenko, op. cit, p. 131; Alekseeva L.; Belashko V.; Voronov G.; Golubev V.; Danchenko V.; Zlobin T.; Shubin A. (1992): Yuzhnye Kuril'skie ostrova (Prirodno-ekonomicheskii ocherk), Yuzhno-Sakhalinsk, Russian Academy of Science, Far Eastern Branch, p. 135.

${ }^{42}$ Vysokov et al., "Istoriya Sakhalina i Kuril'skikh ostrovov...", op.cit., p. 521; Williams, Brad (2007): Resolving the Russo-Japanese Territorial Dispute, Hokkaido-Sakhalin relations, London; New York, Routledge, p. 140.

${ }^{43}$ Differences in the survey results show that around sixty to seventy percent of Shikotan residents supported the return, with conditions, of all four islands. The percentage of supporters decreased amongst Kunashir and Iturup residents, in that order. Around seventy to eighty percent of Iturup residents were opposed the handover. Also, since 2000 the number of handover supporters on Shikotan and Kunashir has decreased. NHK shuzai han (1993): Hoppo yonto, Chishima retto kiko, Tokyo, NHK Shuppan, p. 152; Iwashita, Akihiro (2005): Hopporyodo mondai, Tokyo, Chuko Shinsho, pp. 177-181; Williams, op. cit., pp. 132-134; 140-143; Williams, Brad: "The Russo-Japanese Visa-free Exchange Program: Opportunities and Limits", East Asia: An International Quarterly, vol. 20, Iss. 3 (Autumn 2003), pp. 116-118.
} 
program, residents may have compared this to the economic woes of the Southern Kuriles and felt resentment towards the Russian government for having ignored them. In September 1991, the Russian Deputy Foreign Minister GeorgiiKunadze visited three of the South Kurile Islands and spoke candidly about the possibility of abiding by the Joint Declaration. As the specific methods and conditions of the handover were also discusses in central and regional newspapers, in early 1990s it seems that Shikotan residents believed that an eventual handover to Japan was now unavoidable. ${ }^{44}$

The Japanese government prohibits any economic activities with the Northern Territories, under the reasoning that this would undermine its claim and be default recognise Russia's effective control. Thus, the Japanese people participating in the visa-free exchange program cannot respond to any business proposals initiated by the Russian residents. Furthermore, the Russian side has gradually lost its interest in interactions with Japan, and there has been an increase in residents abandoning the struggling island economy and migrating to the Russian mainland. The population of the Kuriles peaked at 29,500 people in 1989 , but has been diminishing ever since 1990 and in 2002 passed below 20,000 people. ${ }^{45}$ The Kuriles have suffered the peculiar experience of losing one third of their population in just twelve years. $^{46}$

From 2000, under the initiative of the then Lower House member Muneo Suzuki and as part of broader humanitarian aid, Japanese construction companies built warehouses, dwellings and diesel power generation facilities on the Southern Kuriles, though these activities finished with Suzuki's demise.

Since then, the Sakhalin regional government, having maintained its unyielding stance on the territorial issue, began to apply pressure to the visa-free exchange program. In July 2003, the Sakhalin parliament petitioned President Putin and members of both houses of the Russian Federal Assembly for the program's termination, arguing that "Japan is using the visa-free exchanges as a vehicle for ideological purposes towards the residents of the Southern Kurile Islands". ${ }^{47}$ When a fatal shooting incident of a Japanese fishing boat crew member by Russia's border patrol occurred in August 2006, the mayor of Nemuro City also proposed that the exchanges be suspended, and what had originally been designed for the spread of goodwill between Japan and Russia instead became a source of trouble. In 2009, Russia announced that it would stop accepting Japanese humanitarian aid, and this has since been limited to accepting medical aid only.

\footnotetext{
${ }^{44}$ In an August 1992 edition of Izvestiya appeared a discussion on various issues that would arise upon the transfer of Shikotan to Japan, such as the question of compensation from Japan for property left behind by those leaving the island, as well as problems around citizenship under Japanese sovereignty for those that stayed. (Kondrashov, Stanislav: "Mukizamireniya s Yaponiei”, Izvestiya, 14 August 1992.). In September of the same year, a Southern Kurile newspaper discussed the likely legal status of residents after the handover as well as any compensation issues, and wondered out loud whether those wishing to would be able to learn Japanese, or if children would be able to visit Japan on their holidays: "Kunashir Iturup vypaliizterritorial'nogospora. Poka", $\mathrm{Na}$ rubezhe, 1 September 1992.

${ }^{45}$ Russian Academy of Science et. al., op.cit., p.449.

${ }^{46}$ Extreme changes in population are not rare on the Kurile Islands. In 1959 their population was 21, 739 people. When Khrushchev put a stop to the system of "northern privileges" in 1960 around thirty percent of people left the islands, leaving a population of around 15,000 people by 1970 . Afterwards, when this system was reinstated the population returned. An earthquake and tsunami that occurred on 5 November 1957 killed 2,331 people on the Northern Kuriles. Also, as discussed above, around 2,000 people were forced to leave the islands of Shikotan and Habomai in 1957: Vysokov et al., "Istoriya Sakhalina i Kuril'skikh ostrovov...", op.cit., p. 484; Russian Academy of Science et al., op.cit., p. 135, 449.

${ }^{47}$ Ponamarev, Sergei (2008): Ya Vam pishu, Yuzhno-Sakhalinsk, p. 23.
} 
A Social and Economic Development Plan for the Kurile Islands, which was initially proposed in 1994 but did not materialize, was re-introduced as a special federal project to run between 2007 and 2015. This time federal government invested significantly. On Iturup, Kunashir and Shikotan islands sealed roads, airfields, ports, hospitals, schools and homes were constructed. Ironically, Japanese made construction vehicles and materials were deployed in this process, being delivered to the construction sites via Sakhalin.

In July 2011 representatives of Kunashir and Iturup greeted a Japanese 'no visa' delegation to the islands with a statement that "both President Medvedev and the governor of Sakhalin are showing great interest in the development of the Southern Kuriles" ${ }^{48}$ Amongst the island residents themselves there is now a spreading recognition that there will be no handover to Japan.

\section{The Border Region: Myths and Realities}

\subsection{The Border Town: Nemuro}

The Nemuro region of Hokkaido has been impacted more than any other by the territorial dispute, since the end of WWII until today. Having lost access to waters required for its predominant industry of fishing, it has also received former island residents from the Southern Kuriles and been deeply disturbed by the seizures made by both the Soviet Union and Russia. As Soviet authorities employed the seizures to send political messages, their frequency would increase during moments of tension between Japan and the Soviet Union. The highest number of seizures recorded was in 1955-1956, coinciding with drawn out negotiations between the two countries. ${ }^{49}$ Because of the richness of the fishing waters which surround the Southern Kuriles, poaching became widespread and various groups emerged to conduct illegal trade with the Soviet Union/Russia.

After many years of hostility towards the Soviet Union, Nemuro underwent a sudden change in 1991 by supporting exchanges with the Southern Kuriles, and emerging as a place in which solutions to the territorial dispute might be worked towards. Illegal fishing vessels were eradicated; Russian ships were permitted entry into Nemuro port, and, in the following year, ships for the visa-free exchange program began operating between Nemuro and the Southern Kuriles. Moreover, Russian fisheries personnel and Southern Kurile residents began to stay in Nemuro, an area previously prohibited to Russians. With more than twenty years having passed without serious incident since Russian people began visiting Nemuro, it can be said that the turnaround in the relationship, from disengagement to engagement, has been successful.

The residents of Nemuro themselves have previously expressed their hopes on two occasions for a resolution of the dispute through the return of only two islands of Shikotan and Habomai. The first occasion was in May 1956, in which an 'Assembly of Nemuro Residents for the Restoral of Japan-Soviet Relations' was held. The declaration stated that "based on a challenging international environment, (the Assembly) calls for the

\footnotetext{
${ }^{48}$ This comment was heard during a visa-free exchange in which the author participated. It was made on Kunashir by Vishirova, Vice-Chariman of the Southern Kurile Regional Assembly on 8 July 2011, and on Iturup by Oshikina, the Chairperson of Kurile Regional Assembly and Head of the Region on 10 July 2011.

${ }^{49}$ The number of seizures made in 1955 was 67 vessels and 440 people. In 1956, the number was 89 vessels and 677 people: Nemuro-shi and Hopporyodo Mondai Taisaku Kyokai, op.cit., p. 92.
} 
commencement of negotiations between Japan and the Soviet Union for the return to Japan of Shikotan and the Habomai Islands and for the establishment of safe fishing conditions in the Nemuro straight". A second declaration was made by the "Assembly of Nemuro Residents for a Japan-Soviet Peace Treaty', held in March 1960. Its declaration called for "the signing of a peace treaty with the return of Shikotan and the Habomai Islands, with an agreement to ensure safe fishing conditions". 50 The "safe fishing conditions" mentioned here refer to the desire to fish without fear of seizures by Soviet authorities. Evidently, Nemuro residents saw the guarantee of these conditions as being every bit as important as the resolution of the territorial dispute itself.

Since then, Nemuro has been actively engaged in the movement, led by the Japanese government, to return the Northern Territories and has not issued any compromise plan at odds with the government's own position. There are several possible reasons for this. Firstly, the era of crisis in which Nemuro received former Southern Kurile islanders while being deprived of its fisheries has now passed. Secondly, as a region impacted by the territorial dispute Nemuro has received financial support from the government. Finally, it was generally thought that petitioning the nation more broadly on the issue, with the support of the government, would be more effective in solving the dispute.

During the 1990s, Nemuro began to experience steady economic benefits from dealings with Russian fishing vessels, from the visits of participants in visa-free exchanges and from the humanitarian aid to the Southern Kuriles. Southern Kurile residents also purchased all types of goods, from food to used vehicles, in Nemuro. During this period, in which the territorial dispute approached a resolution, plans were envisaged for enhanced economic activity with the Southern Kuriles. In 1995, the Nemuro branch of Junior Chamber International released a plan for the economic development of Nemuro City and the Southern Kuriles by creating a free-trade zone in the region, while in 1998 the Nemuro Chamber of Commerce set up a Russian Economic Exchange Project Office. ${ }^{51}$ In recognition of the fact that the Southern Kuriles had once been part of the Nemuro fishery, the emergence of a 'Nemuro-Northern Territories Economic Zone' was strongly anticipated.

Nevertheless, since 2000 these hopes have been betrayed: Japan and Russia failed to sign a peace treaty, Japanese relations with Russia remained tumultuous and the reforms of local financial affairs begun by former Prime Minister Koizumi in 2001 further damaged Nemuro's economy. The 2005 Japan-Russia summit meeting, held 150 years after the signing of the Treaty of Shimoda and 100 years after the end of the Russo-Japanese War, ended with no particular outcome. In response to this, Nemuro's deputy mayor commented, "the anger of Nemuro citizens has erupted". 52 In June 2006, Mayor Hiroshi Fujiwara declared in council chambers that he would be the first Nemuro mayor in history to support the 'two islands first' solution (i.e. to continue negotiation on Iturup and Kunashirafter the return of Habomai and Shikotan) in order to break the deadlock in the dispute. ${ }^{53}$

In February 2006, Nemuro and four other municipalities located on Hokkaido's eastern coast delivered a 'Proposal for the Renewal of Efforts to Solve the Northern Territories Dispute' to the national government. While the document did not directly criticize the government, it asserted that the current "conditions require a readiness to deal with protracted

\footnotetext{
${ }^{50}$ Takakura, Shin'ichiro (ed.) (1968): Nemuroshishi, vol. 1, pp. 576-578.

${ }^{51}$ Junior Chamber International Nemuro (1995): Marino Free Zone, Nemuro.

${ }^{52}$ Ishigaki, Masatoshi (2011): "Kokkyo to yobenai machi, Nemuro no chosen", at http//:borderstudies.jp/essay/live/pdf/Borderlive7.pdf.

${ }^{53}$ Hokkaido Shimbun, 28 June 2006.
} 
negotiations for the return of the Territories" and thus a "more strategic approach leading to their return" was necessary. The submission also went on to illustrate the willingness of Nemuro, as the "mother city of the Northern Territories", to carry on with the political movement for their return. It also outlined the losses suffered by Nemuro and surrounding areas as a result of the territorial dispute and called for concrete economic stimulus for the region. The submission also listed several areas of economic undertakings with the Southern Kuriles and far eastern Russia that would benefit Nemuro, for example, having Nemuro-based firms participate in the construction of infrastructure announced in the Russian government's 2007-2015 Social and Economic Development Plan for the Kurile Islands; receiving compensation for the supply of goods to the Southern Kuriles, and expanding the safe fishing zone. $^{54}$

The population of Nemuro in the 1960s had been close to 50,000 people. In 2010 it dropped below 30,000 , and by the end of 2011 fell to as low as 29,139 people. ${ }^{55}$ Compared to twenty years ago, the roles have been reversed: it is Nemuro now seeking economic exchange with the Southern Kuriles, which has been energized by Russian investment and construction.

\subsection{The Foundations of Territorial Myths}

The starting point of the 'Movement for the Return of the Northern Territories' is considered to be a petition sent to General MacArthur, Supreme Commander of the Allied Powers, by former Nemuro mayor IshisukeAndo in December 1945. In 1950 the group led by Ando integrated with several other Hokkaido based organizations and begun demanding the return of the entire Kurile chain.

The return of the four islands became national policy goal from the middle of the 1955 Soviet-Japan negotiations. Japan began to argue that "the four islands are inherently part of Japanese territories and do not belong to the Kuril Islands which were abandoned as a result of the San Francisco Peace Treaty". After this, because it was not possible to reason the "Southern Kurile Islands do not belong to the Kurile chain", Japan began to use the term 'Northern Territories' instead of 'Southern Kuriles'.

In 1964, Japan's Ministry of Foreign Affairs released a national directive requesting that the use of 'Southern Kuriles' be avoided. In the following year of 1965, Nemuro City also began to use the term 'Northern Territories' in place of 'Southern Kuriles'. The 'mission' of the city official in charge of territorial issues was now to be "awakening public opinion and conducting public awareness campaigns". ${ }^{56}$ It was assumed that if movements local to Nemuro were to spread nation-wide, this would hasten the resolution of the dispute. Also in 1965, a lobby group for the return of the territories launched by the mayor of Nemuro became a semi-governmental corporation with the approval of the Minister for Foreign Affairs. 'The Alliance for the Return of the Northern Territories' oversaw the irredentist movement on Hokkaido.

Furthermore, in 1969 yet another semi-governmental organization, the 'Policy Association for the Northern Territories Problem' was established by the Diet. The motivation behind this, it was explained, was that because "public opinion on the matter is regrettably sluggish... There is an acute need for an organization able to carry out national awareness and

\footnotetext{
${ }^{54}$ Hopporyodo Rinsetsu Chiiki Shinko Taisaku Nemuro kannai Shi-cho Renraku Kyogikai (2006): Hoppo ryodo mondai no kaiketsu ni muketa torikumi, Nemuro, Saikochikuteigensyo.

${ }^{55} \mathrm{Nemuro}$ city official website, at http://www.city.nemuro.hokkaido.jp/dcitynd, nsf.

${ }^{56}$ Nemuro-shi and Hopporyodo Mondai Taisaku Kyokai, op. cit., p. 79.
} 
publicity campaigns" in regard to the return of the Northern Territories. ${ }^{57}$ On the initiative of the Association, a 'Citizens Assembly to Demand the Return of the Northern Territories' (Hoppōryōdohenkanyōkyūundōkenminkaigi)was organized in each of Japan's forty-seven prefectures and the knowledge about the 'Northern Territories problem' spread throughout Japan. 58

Posters, pamphlets and maps in support of the return of the Northern Territories were distributed across the nation, and a discourse concerning these 'inherently Japanese territories' spread nationwide. These remote islands, to which few Japanese have ever paid a visit or had even heard of, began to be imagined as Japanese territory that should have been regained from the Soviet Union. Various strategies were also prepared for the area around Nemuro: a small museum and a monument explaining the 'Northern Territories problem' were built on the area of coastline from which Kunashir and the Habomai islands are visible and a program to encourage Japanese to 'see the Northern Territories with your own eyes' was established. When 'Northern Territories Day' was enacted in 1981, the Prime Minister, various politicians and high government officials began visiting the tip of the Nemuro Peninsula to conduct 'inspections of the Northern Territories'. 59

These efforts are not directed at Russia, but instead towards the Japanese people themselves, arguing the need for the Northern Territories to be returned, and has continued even after the fall of the Soviet Union. The Japanese government contends that "in order to vigorously push forward the negotiations with Russia, the consensus of opinion amongst the Japanese people on the return of the Northern Territories must be strengthened, and this must continue to be clearly expressed". ${ }^{60}$ Because of this, a similar campaign to that of Cold War era efforts for the return of the islands continues.

Challenging Japan's territorial demands, there are also Russian installations to declare Russian ownership of the Southern Kuriles. Many of these contradict historical facts related to the islands. For example, there is a monument that gives an impression of ancient Russian position of the disputed territories as it is erected to celebrate the 'incorporation of Iturup into the Russiam Empire'. Another is a war memorial that gives the impression of battles having taken place on the Southern Kuriles during WWII. ${ }^{61}$

In 2010 Russia designated $2^{\text {nd }}$ of September, the day on which Japan signed the instrument of surrender, as the anniversary of the end of WWII in the Pacific. On this day, grand ceremonies are held across the Kurile Islands and local newspapers run articles on 'the liberation of the Kurile chain' by the Soviet Army. ${ }^{62}$ In 2011, the Southern Kuriles celebrated the $65^{\text {th }}$ anniversary of its founding as a Russian region in 2011 , while in 2012 the $65^{\text {th }}$ anniversary of the establishment of the Sakhalin Region was also held.

On occasion, the movement against the return of the Southern Kuriles that has emerged on Sakhalin shadows the Japanese campaign, for example in its selective referencing of

\footnotetext{
${ }^{57}$ Hopporyodo Mondai Taisaku Kyokai (ed.) (1996); Hoppo ryodo henkan undo 50 nenshi, Tokyo, p. 91.

${ }^{58}$ In Shimane Prefecture, to which Takeshima is attached, a 'Citizens Assembly to Demand the Return of Takeshima and the Northern Territories' was established.

${ }^{59}$ The date of 'Northern Territories Day' is 7 February, the date on which the Shimoda Treaty first established the border between Japan and Russia.

${ }^{60}$ Ministry of Foreign Affairs of Japan, op.cit., p. 42.

${ }^{61}$ The particular moment mentioned on Iturup states that "On the $5^{\text {th }}$ of June 1778 the Ainu people of this island received Russian nationality". This is probably a gross exaggeration of the historical fact that Iturup was visited in that year by a Russian called Dmitri Shabalin.

62،"Tak zakonchlas' vtoraya mirovaya voina”, Krasnyimayak, 2 September 2011.
} 
historical documents, maps, slogans and pamphlets. Sakhalin's regional flag, introduced by the Sakhalin regional parliament in 1997, contains a V shaped image of Sakhalin and the Kurile chain to emphasize the unity of the islands. Additionally, hanging from a fish processing plant on Iturup Island a large sign declares that "The Kuriles are Russian Lands".

Thus, both Japan and Russia have continually declared to their own people that the Northern Territories/Southern Kuriles belong to them.

\section{Conclusion}

At a 'Mass Rally to Demand the Return of the Northern Territories', held in Tokyo on the 'Northern Territories Day' (7 February) in 2013 Japanese Prime Minister Shinzo Abe declared that he would "pursue the negotiations with fervent determination". ${ }^{63}$ However, on that very day it was revealed that two Russian fighter jets had illegally intruded into the airspace above the north-eastern part of Hokkaido, for which Japan criticized the Russian government the following day. This news summoned memories of the Cold War era, during which the Soviets would step up seizures of Japanese fishing vessels off the Southern Kuriles whenever an event concerning the Northern Territories was held in Japan.

Despite the fact that a quarter of a century has passed since the reopening of Japanese and Russian territorial negotiations, there is no prospect of the issue being resolved. Though one cause is the inability of Japan and Russia to negotiate a problem that has become very complicated during the Cold War era, the emergence of two different conceptions of justice around the Southern Kuriles is a further impediment to the resolution of the dispute. On one hand, having been completely ruled by the Soviet Union from immediately after WWII and with a history of isolation from the rest of the world, for the Russian people there is no question that the Southern Kuriles have been part of Russia for a long time. Conversely, for the Japanese, who have been completely removed from the islands and now no longer have an understanding of actual conditions there, an abstract sense that the islands are somehow 'inherently Japanese' has become entrenched in the society.

Though both the Japanese and the Russian governments should act to break down some of the myths that their nations maintain concerning the territories, in reality both sides exploit these myths and moreover rely upon them. In 1989, the Japanese government by cabinet agreement decided to prohibit uncontrolled crossings into the Northern Territories by Japanese, reasoning that it would be unacceptable for Japanese nationals to obtain a visa from Soviet authorities while they continued to illegally occupy the islands. This cabinet agreement has been continually renewed even after the fall of the Soviet Union. Japanese citizens are not only prohibited from economic activities in the Northern Territories, but they are not even allowed to visit what is purportedly the territory of their own country. Permission to visit the Territories is granted only in limited cases such as the via visa-free exchange program and for those visiting family graves. Furthermore, in recent years high level government officials from Russia, above all President Medvedev, frequently visit the Southern Kuriles, each time declaring them to be Russian territory and impeding any further progress in the negotiations.

The residents of Nemuro and the Southern Kuriles, which have essentially become the border zone between Japan and Russia, have shown a flexible approach towards the territorial

\footnotetext{
${ }^{63}$ Asahi Shimbun, 8 February 2013.
} 
dispute. After controlled interactions began in 1991 for the first time since WWII, both regions have eschewed any hostility and amicable relations between them have been maintained. However, with a combined population of a little under fifty thousand people, neither yields sufficient influence towards their own government. During the period of turmoil just before and after the fall of the Soviet Union, the hopes of the Southern Kuriles were invested in Japan. But as the Russian economy has stabilized these hopes have reverted back to Russia. The previous indigenous inhabitants of the Kuriles (the Ainu) have all but disappeared, and the former Japanese islanders are now reaching the end of their life expectancy.

In recent years, new considerations have emerged that may potentially impact on the territorial dispute. Primarily these relate to environmental protection, natural resource management and disaster prevention. More specifically, these are issues concerning the protection of the unique ecologies on the Kurile Islands, appropriate exploitation of their rich marine resources by Russia and earthquake and tsunami safety measures. There is also the issue of how Japan should involve itself in the economic development of the Southern Kuriles. Russia has shown ambitions to develop this geopolitically and economically important region positioned in "the contact zone between the Pacific Ocean and Eurasia". 64 There is also the possibility that other countries may embark on investments in the Southern Kuriles, linking them by air and shipping routes to other countries. Other developments, such as the opening up of Arctic shipping routes due to global warming and security issues in the North Pacific are also changing the global relevance of the Southern Kuriles. If the rise of nationalist sentiments and the impasse between Japan and Russia continue, both countries will likely need to shelve any territorial issues for the time being and jointly seek ways to stabilize and develop this border region.

\footnotetext{
${ }^{64}$ Russian Academy of Science et al., op. cit. p. 109.
} 